\title{
EFFECT OF CLIMATE CHANGE ON THE DISTRIBUTION OF MAGNOLIA SCHIEDEANA: A THREATENED SPECIES
}

\author{
Suria Gisela Vásquez-Morales ${ }^{1}$, Oswaldo Téllez-Valdés ${ }^{2,5}$, María del Rosario \\ Pineda-López ${ }^{1}$, Lázaro Rafael Sánchez-Velásquez ${ }^{1,3}$, Norma Flores-Estevez ${ }^{1}$ \\ Y HÉCTOR ViVEROS-Viveros ${ }^{4}$ \\ 'Instituto de Biotecnología y Ecología Aplicada, Universidad Veracruzana, Xalapa, Veracruz, Mexico \\ ${ }^{2}$ Laboratorio de Recursos Naturales UBIPRO, Facultad de Estudios Superiores de Iztacala, \\ Universidad Nacional Autónoma de México, Tlalnepantla, Estado de México, Mexico \\ ${ }^{3}$ Coordinación Universitaria para la Sustentabilidad, Universidad Veracruzana, Xalapa, Veracruz, Mexico \\ ${ }^{4}$ Instituto de Investigaciones Forestales, Universidad Veracruzana, Xalapa, Veracruz, Mexico \\ ${ }^{5}$ Author for correspondence: tellez@unam.mx
}

\begin{abstract}
The effects of climate change on biodiversity are imminent, and these turn out to be particularly alarming for the tropical montane cloud forest. The disappearance of fragments of this forest is expected, along with some of their most characteristic species, such as Magnolia schiedeana. Mexico, through the National System of Protected Natural Areas, must consider protection strategies for those species distributed within the Protected Natural Areas that will be affected by the climate change. This study delimits the distribution of M. schiedeana in Mexico, through ecological niche and future distribution modeling under two periods: years 2040 and 2080. These distribution models tend to move towards northeastern Mexico. The potential distribution of this species declines by $0.36 \%$ and $1.94 \%$ in the first and second periods, respectively. From this result, the future role of National System of Protected Natural Areas in the long-term conservation of M. schiedeana was analyzed, prompting a proposal to focus conservation efforts on the following Protected Natural Areas: (1) At the federal level: Biosphere Reserve Sierra Gorda and Cañón de Metztitlán, Cuenca del Río Necaxa and El Potosí, National Park El Chico, Cofre de Perote, Pico de Orizaba and Los Mármoles, and Nevado de Toluca. (2) At the state level: Cerro de las Culebras, Cerro de la Galaxia, Cerro de Macuiltepetl, El Tejar Garnica, Francisco Javier Clavijero, La Martinica, Molino de San Roque, Pacho Nuevo and Predio Barragán.
\end{abstract}

Key words: bioclimatic models, conservation, endangered species, potential distribution.

Resumen: Los efectos del cambio climático sobre la diversidad biológica son inminentes, y resultan especialmente alarmantes para el bosque mesófilo de montaña. Se prevé la desaparición de fragmentos de bosque y de algunas especies más características, como Magnolia schiedeana. México, mediante el Sistema Nacional de Áreas Naturales Protegidas, debe considerar estrategias de protección para aquellas especies en áreas naturales protegidas que resultarán afectadas a causa del cambio climático. Este estudio delimita la distribución de M. schiedeana, por medio del modelado del nicho ecológico, en México, y su distribución futura en dos periodos: al año 2040 y al año 2080. Los resultados muestran que los modelos de distribución tienden a desplazarse hacia el noreste de México. En el primer periodo, la distribución potencial disminuye $0.36 \%$ y, en el segundo periodo decae hasta $1.94 \%$. Con base en la distribución potencial, se analizó la función que el Sistema Nacional de Áreas Naturales Protegidas desempeñará en la conservación de $M$. schiedeana a largo plazo, con lo cual se propone centrar los esfuerzos de conservación en las siguientes áreas naturales protegidas: (1) A nivel federal: Reserva de la Biosfera Sierra Gorda y Barranca de Metztitlán, Cuenca del Río Necaxa, El Potosí, Parque Nacional El Chico, Cofre de Perote, Pico de Orizaba y Los Mármoles, y el Nevado de Toluca. (B) A nivel estatal: Cerro de las Culebras, Cerro de la Galaxia, Cerro de Macuiltepetl, El Tejar Garnica, Francisco Javier Clavijero, La Martinica, Molino de San Roque, Pacho Nuevo y Predio Barragán.

Palabras clave: conservación, distribución potencial, especies en peligro de extinción, modelos bioclimáticos.

A nthropogenic activity has led to global temperature rises, affecting ocean temperatures, ice and snow coverage, and cooling of the lower stratosphere (Magaña, 2004). It has also caused the concentration of atmospheric $\mathrm{CO}_{2}$ to rise from $280 \mathrm{ppm}$ to $370 \mathrm{ppm}$ since the mid-nineteenth century (IPCC, 2001). These are changes that will have dramatic consequences for ecosystems by altering the abundance and distribution of their constituent species (Hardy, 
2003; Tews, 2007; Aitken et al., 2008), as well as causing a gradual decline in the environmental services they provide. These environmental changes make it possible to predict that $11 \%$ of the world's endemic biota could become extinct within the next 100 years (Malcolm et al., 2006). Using species distribution models and future scenarios, it is possible to predict the response of species to such climate change and thus, propose adaptation and mitigation measures at both the ecosystem and species level (Hilbert et al., 2004; Magaña et al., 2004; Li and Hilbert, 2008; Tejeda, 2009).

It is intended for tropical montane cloud forest (TMCF) of Mexico, a shift towards lower latitudes and higher altitudes (Foster, 2001). Likewise Estrada-Contreras (2010) found an impairment in the potential distribution of Quercus skinneri Benth (endemic to this forest) with a decrease of $100 \%$ in current distribution, and a decrease of $50 \%$ for the following seven species Cinnamomum effusum (Meisn.) Kosterm., Miconia glaberrima (Schltdl.) Naudin, Oreopanax xalapensis (Kunth) Decne. et Planch., Palicourea padifolia (Humb. et Bonpl. ex Schult.) C.M. Taylor et Lorence, Quercus germana Schltdl. et Cham., Q. xalapensis Bonpl., and Ulmus mexicana (Liebm.) Planch. Consequently, there will be three options for these species: migrate to optimal zones for survival, adapt to the prevailing environmental conditions, or become extinct (Holt, 1990; Lindenmayer et al., 1996; IPCC, 2001).

The TMCF in Mexico is known for its archipelago-type distribution, and is located in an altitude range between 1,000 and 3,000 masl. Its main features are the flora, consisting of a mixture of the neotropical and holarctic species, and extended periods of fog cover (Rzedowski, 1978, 1996). Villaseñor (2010) reports 6,790 species of vascular plants, 1,625 genera, 238 families, including 2,361 endemic species; characteristic genera of this ecosystem are Carpinus, Engelhardtia, Fagus, Liquidambar, Magnolia, and Ostrya, among others. It is an ecosystem in danger of extinction that features high levels of disturbance and fragmentation, with 83 species in danger of extinction, 206 threatened, and 175 vulnerable (CONABIO, 2010; SEMARNAT, 2010; Villaseñor, 2010; González-Espinosa et al., 2011).

In Mexico, there are 21 species of the family Magnoliaceae, specifically Magnolia schiedeana Schltdl. It is found exclusively in TMCF, in the central portion of the watershed of the Gulf of Mexico, and is categorized as threatened to become extinct because of the destruction of its habitat (Cicuzza et al., 2007; Jiménez-Ramírez et al., 2007; SEMARNAT, 2010; Vázquez-García et al., 2012). The populations are found dispersed within remnants of TMCF, which are being steadily absorbed by uncontrolled urban expansion.

When the climate scenarios are added to this situation, TMCF appears highly vulnerable on account of the predicted fluctuations in temperature and precipitation (Markham, 1998; Pounds et al., 1999; Foster, 2001; Midgley et al., 2002; Bubb et al., 2004; Sáenz-Romero et al., 2010; Ponce-
Reyes et al., 2012; Rojas-Soto et al., 2012), and many of its species are likely to suffer local extinctions.

Protected Natural Areas (PNA) has been considered the best option for biodiversity conservation (Bruner et al., 2001). However, this option requires reassessment in the face of climate change, with an examination of the reserve network and its efficiency relating to the long-term conservation of flora and fauna (Halpin, 1997; Hannah et al., 2007; Lawler, 2009), as well as the provision of environmental services (Torres and Guevara, 2002; Bezaury, 2009). It is estimated that PNAs contain $15 \%$ of the terrestrial carbon and provide ecosystem services for the reduction of disasters, supply of water, food, and public health (Dudley et al., 2010).

In Mexico, only $12 \%$ of the national territory is allocated to biodiversity conservation (CONANP, 2011) and, in the state of Veracruz, conservation efforts are focused on 19 PNAs decreed at the federal level and 18 at the state level (SEDEMA, 2012a, b). Nevertheless, these PNAs are harmed day by day from human activities, and some have been absorbed by the urban development with no knowledge, in many cases, of the species within the territories apportioned for conservation in Veracruz (CONABIO, 2010).

The species distribution models and future scenarios predict the shift in the distribution of species; therefore, it can be inferred that species can enter and leave the territory allocated to conservation (Téllez-Valdés et al., 2006; CONANP, 2010). For this reason, it is important to analyze the effects of climate change on species distribution and monitor their future displacement with respect to the PNAs (Téllez-Valdés and Dávila-Aranda, 2003; Hannah et al., 2005, 2007; Mansourian et al., 2009; Contreras-Medina et al., 2010). Currently, ecological niche modeling has become an essential tool for determining the potential distribution and ecological requirements of species (Soberón and Peterson, 2005; Irfan-Ullah et al., 2007; Peterson, 2009).

The BAM diagram of Soberón and Peterson (2005) mention that the modeling of the ecological niche is governed by the fundamental niche and realized niche. The fundamental niche is defined as the geographic area with the appropriate combination of abiotic factors allowing the species to survive, grow, and reproduce; and the realized niche is the geographic area in which the interaction takes place with other species (Soberón and Peterson, 2005).

Different software for modeling potential species distribution including GARP, BIOCLIM, DOMAIN, MaxEnt, to name a few, and it has been proven that MaxEnt has a method with greater yield and reliability than other software (Elith $e t$ al., 2006). MaxEnt is a statistically used algorithm to make predictions or inferences from incomplete information, and estimates the species distribution through the search of the probable distribution of maximum entropy (nearest the occurrence data of the species; Phillips et al., 2006).

The principle of maximum entropy guarantees that the 
MaxEnt distribution probability meets all the restrictions of the data distribution of species presence. The probability of unknown $\pi$ distribution is on a finite combination $X$ (pixel combination in the study area). The $\pi$ distribution assigns a $\pi(x)$ probability that is not negative on each point $x$ and these probabilities add up to 1 , with $\ln$ being the natural logarithm. The $\pi$ approach is also the $\hat{\pi}$ distribution approach. The $\hat{\pi}$ entropy is defined by the following formula:

$$
H(\hat{\pi})=-\sum_{x \in X} \hat{\pi}(x) \operatorname{In} \hat{\pi}(x)
$$

Entropy is not negative and the natural logarithm of the number is the element $X$. The procedures applied in this software are described in detail by Phillips et al. (2006).

In this study, we evaluated the potential effects of climate change on populations of Magnolia schiedeana, considering the MDI-ECHAM5 scenario in two periods (years 2040 and 2080), using potential distribution models at a spatial resolution of $1 \mathrm{~km}^{2}$. We also identified protected areas suitable for long-term preservation.

\section{Methods}

Current potential distribution of Magnolia schiedeana. The area distribution of the species was constructed using a database that includes 335 records of $M$. schiedeana, and which was pieced together from the specimens found in the following herbaria: XALU from the Universidad Veracruzana, Xalapa campus, XAL from the Instituto de Ecología, A.C., and MEXU from the Universidad Nacional Autónoma de México, as well as the online databases Tropicos from the Missouri Botanical Garden and REMIB-CONABIO (Red Mundial de Información sobre Biodiversidad/World Information network on Biodiversity - National Commission for Knowledge and Use of Biodiversity/Comisión Nacional para el Conocimiento y Uso de la Biodiversidad).

Mean monthly values of minimum and maximum temperatures and precipitation recorded from a standard network of meteorological stations were interpolated, using the Thin-Plate Smoothing Spline method of the ANUSPLIN 4.1 package (Hutchinson, 1991, 1995a, b, 1997; Hutchinson and Gessler, 1994; Houlder et al., 2000). Specifically, 4,200 stations for temperature and 6,218 stations for precipitation were used to produce the digital climatic layers (Téllez et al., 2011). The spatial resolution of the layers and the digital elevation model was $1 \mathrm{~km}^{2}$ from the GTOPO 30 project (https://lta.cr.usgs.gov/GTOPO30).

The BIOCLIM software of the package ANUCLIM 6.1 was used to generate 19 bioclimatic variables (Table 1) from the combination of the mean monthly layers of temperature and precipitation above referred, from which the bioclimatic profile of Magnolia schiedeana was also extracted (Lindenmayer et al., 1991; Téllez-Valdés and Dávila-Aranda, 2003; Téllez-Valdés et al., 2004, 2006; Villaseñor and Téllez-Valdés, 2004).
The records where the species is found were used along with the 19 bioclimatic variables to perform a principal component analysis to identify those variables that provide the greatest explanation of the variance of the climatic values in which the species records are distributed and to reduce the autocorrelation.

The seven resulting bioclimatic variables highlighted by the principal component analysis were converted to the ASCII format according to the MaxEnt 3.3.3a software requirements (Table 1), to generate the potential distribution for the species in question.

To generate the current potential distribution models of Magnolia schiedeana, first we generated a model using the jackknife analysis to identify which of the seven selected variables contributed most as regards percentage to the explanation of the variance in which the sample is distributed (species records). The models were calibrated from a random sample of $75 \%$ to generate the model. The remaining $25 \%$ was used to assess the accuracy of the model, and compared using the ROC curve (the AUC index). The models produced were evaluated in order to verify whether the performance differed from that obtained by chance. The model was checked by reducing the environmental space from 10,000 (per omission) to 1,000 cells.

Furthermore, MaxEnt was prevented from extrapolating

Table 1. Bioclimatic variables and values used to generate the current and future potential distribution of Magnolia schiedeana (Minimum - Maximum values, Mean \pm Standard Deviation). ${ }^{*}=$ Bioclimatic variables with higher variance explained through which distributes the sample (records of the species).

\begin{tabular}{lll}
\hline \multicolumn{1}{c}{ Bioclimatic variables } & \multicolumn{1}{c}{ Values } \\
\hline 1 & Annual mean temperature $\left({ }^{\circ} \mathrm{C}\right)$ & $10.1-22.6(16.90 \pm 1.34)$ \\
2 & Mean diurnal range $\left({ }^{\circ} \mathrm{C}\right)^{*}$ & $8.20-13.6(9.60 \pm 0.639$ \\
3 & Isothermality $\left({ }^{\circ} \mathrm{C}\right)$ & $0.55-0.66(0.59 \pm 0.01)$ \\
4 & Temperature seasonality (coefficient & $0.44-1.11(0.66 \pm 0.05)$ \\
& of variation, $\%)^{*}$ \\
5 & Max temperature of warmest period $\left({ }^{\circ} \mathrm{C}\right)$ & $18-33.4(25 \pm 1.30)$ \\
6 & Min temperature of coldest period $\left({ }^{\circ} \mathrm{C}\right)^{*}$ & $2-12.70(8.7 \pm 1.29)$ \\
7 & Temperature annual range $\left({ }^{\circ} \mathrm{C}\right) *$ & $14.6-22.9(16.3 \pm 0.91)$ \\
8 & Mean temperature of wettest quarter $\left({ }^{\circ} \mathrm{C}\right)$ & $10.6-25.1(18 \pm 1.52)$ \\
9 & Mean temperature of driest quarter $\left({ }^{\circ} \mathrm{C}\right)^{*}$ & $8.7-19.3(15 \pm 0.95)$ \\
10 & Mean temperature of warmest quarter $\left({ }^{\circ} \mathrm{C}\right) *$ & $11.6-26(19 \pm 1.40)$ \\
11 & Mean temperature of coldest quarter $\left({ }^{\circ} \mathrm{C}\right)$ & $8.4-17.9(14.2 \pm 1.17)$ \\
12 & Annual precipitation $(\mathrm{mm})$ & $589-1948(1561 \pm 117.21)$ \\
13 & Precipitation of wettest period $(\mathrm{mm})$ & $32-115(75 \pm 5.75)$ \\
14 & Precipitation of the driest period $(\mathrm{mm})$ & $0-14(9 \pm 3.97)$ \\
15 & Precipitation seasonality $(\mathrm{Coefficient}$ & $53-84(68 \pm 3.14)$ \\
& of variation, $\%)$ & \\
16 & Precipitation of wettest quarter $(\mathrm{mm})$ & $265-979(715 \pm 54.91)$ \\
17 & Precipitation of driest quarter $(\mathrm{mm})^{*}$ & $47-193(158 \pm 17.96)$ \\
18 & Precipitation of warmest quarter $(\mathrm{mm})$ & $177-573(448 \pm 44.25)$ \\
19 & Precipitation of coldest quarter $(\mathrm{mm})$ & $50-217(170 \pm 20.56)$ \\
\hline
\end{tabular}


or applying the clamping option (this is how we did the fastening), to prevent an overestimation. This is based on the proposal in BAM diagram, in which M represents the ability of relocation or spread of the species (Soberón and Peterson, 2005; Peterson, 2009).

The model was refined with a maximum of 1,000 points of environmental background $\left(0.0083^{\circ}\right.$, approximately $1 \mathrm{~km}^{2}$ ). Five replicates were run using the bootstrap algorithm. We decided to run 2,000 iterations, since most of the previous exercises finished in fewer than 1,500 iterations. The logarithmic scale of the prediction values was broken where the values of sensitivity and specificity of training were equal, selected using the average model produced by replicates (Phillips et al., 2006).

Potential future distribution of Magnolia schiedeana. Given the uncertainty regarding the magnitude of the effects of climate change, two different periods were proposed (years 2040 and 2080). The first is a conservative scenario, expected for the year 2040, implying temperature increases of 2 to $3.5{ }^{\circ} \mathrm{C}$ and a $5 \%$ reduction in precipitation. The second is a more drastic scenario, expected for the year 2080, where the temperature increase is of 2.5 to $4{ }^{\circ} \mathrm{C}$ with a $10 \%$ reduction in precipitation.

To obtain the potential future distribution model was used Magnolia schiedeana mpi_ECHAM5 (Jungclaus et al., 2005) in two periods (years 50 and 80) in stage A1B, chosen based on the guidance of climate change scenarios at regional scale (Conde et al., 2011), downloaded from the website of Downscaling Global Circulation Model (GMC) (http://www.ccafs-climate.org/). The A1B scenario suggests a future where emissions are medium-high, intervening human activities, such as the increase in population and economy globalization, technology, the use of fossil sources and alternative energy (IPCC, 2007).

Comparison of current and future models with the Protected Natural Areas. Current and future models of Magnolia schiedeana distribution were compared against the polygons of federal and state level PNAs in order to determine the current potential distribution area within the PNAs, as well as to predict what this may become following application of the climate change scenarios. The potential future expansion/contraction of these areas was determined.
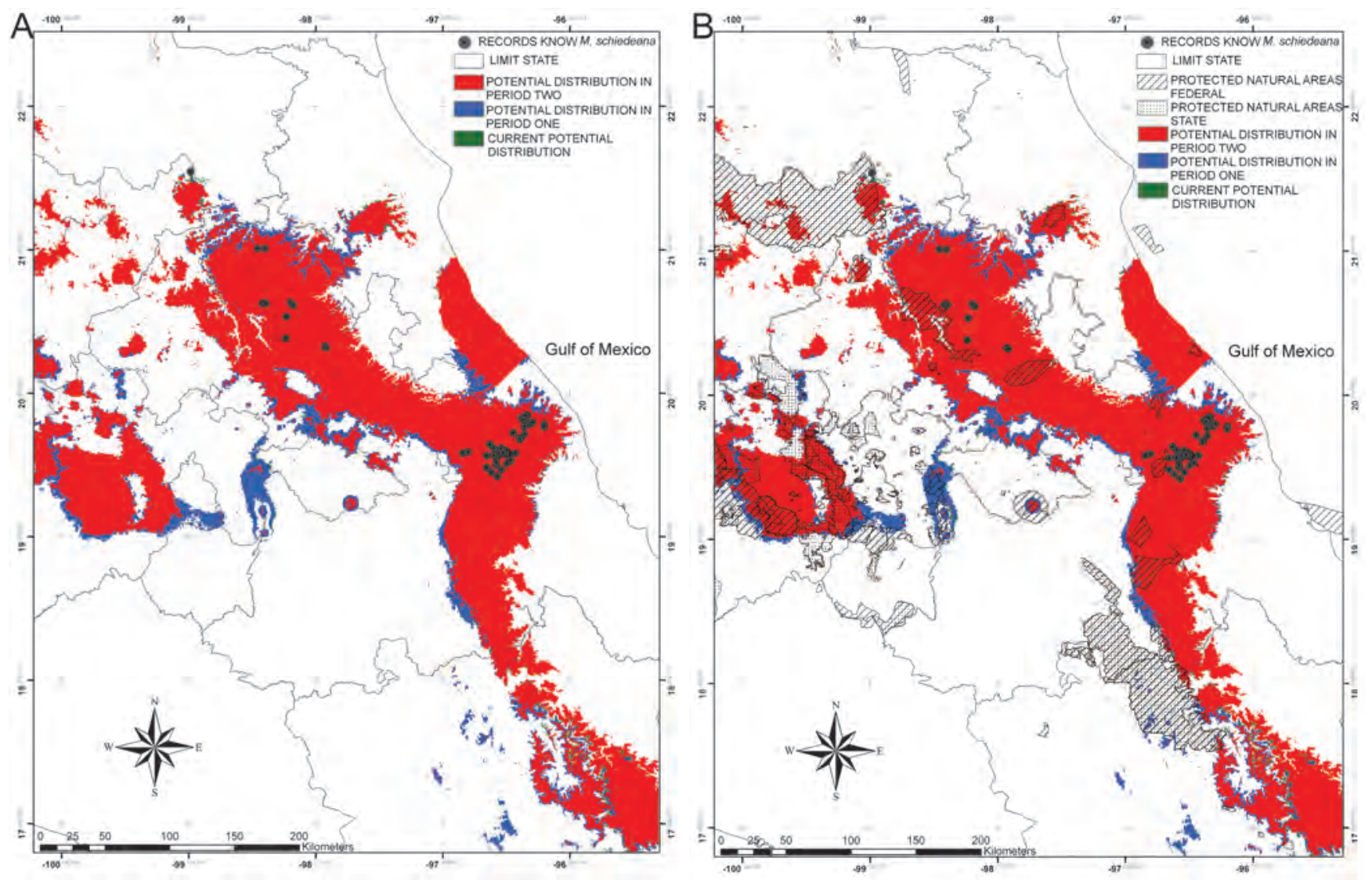

Figure 1. Distribution models of Magnolia schiedeana at ca. $1 \mathrm{~km}^{2}$. Current potential distribution (green) and potential distribution under period 1 (blue: year 2040) and under period 2 (red: year 2080). A) Current potential distribution compared with both periods. B) Comparison between distribution models and Federal and State enacted Protected Natural Areas. 
Data analysis. The current and future models were overlapped with the digital elevation model at the same resolution, in order to identify potential expansion or contraction within the altitudinal variation for the periods with respect to the current potential distribution of Magnolia schiedeana. We performed a variance analysis with a Tukey multiple comparisons test, considering the current model as an independent variable and the two periods as dependent variables, using the software JMP 7.0.1 (SAS Institute Inc., 2007).

Comparison of the current and future models with the PNAs, using GIS ArcView 3.2 (ESRI, 1999), allowed the placement of the PNAs within the current and future distribution areas. The future latitudinal and altitudinal displacement of Magnolia schiedeana distribution within the PNAs was estimated.

\section{Results}

The distribution of Magnolia schiedeana corresponds to that of the TMCF, occurring in gullies or humid slopes where the average annual temperature ranges between $10-21^{\circ} \mathrm{C}$, and annual precipitation is between 589 and $1,743 \mathrm{~mm}$. Table 1 shows the bioclimatic variables that explain the distribution of $M$. schiedeana, in which seven bioclimatic variables contributed almost $98 \%$ to the explanation of the variance in which the sample is distributed (species records), with variables four, six, and 17 adding more than $70 \%$ together.

Comparison of the current and future distribution of Magnolia schiedeana. Our model, in the MaxEnt 3.3.3a, projects potential changes in the distribution areas of M. schiedeana as a consequence of climate change during both periods. The current potential distribution is estimated at $84,640 \mathrm{~km}^{2}$, decreasing to $84,333 \mathrm{~km}^{2}$ in the first period (year 2040) and to $82,995 \mathrm{~km}^{2}$ in the second period (year 2080). Considering the current potential distribution as a base, a displacement of $36.5 \mathrm{~km}^{2}$ to the northeast and a contraction of $5.2 \mathrm{~km}^{2}$ in the west are observed in the first period (year 2040). In the second period (year 2080), a displacement of $6.5 \mathrm{~km}^{2}$ in the east is observed along with a contraction in the west of $54.4 \mathrm{~km}^{2}$ (Figure 1A).

The current potential distribution is at altitude of 1,4332,135 masl, with an average of 1,882 $\pm 687 \mathrm{~m}$, decreasing to $1,426-2,118$ masl with an average of $1,876 \pm 693$ (range: 498-5,471 $\mathrm{m}$ ) in the first period (year 2040), and to 1,2912,052 masl with an average of $1,710 \pm 594 \mathrm{~m}$ in the second period (year 2080), which differs significantly under the second period $(P<0.0001)$ (range: 709-4,837 masl). Figure 2 shows the elevation of the current and future potential distribution of M. schiedeana in which the box on the diagram indicates the greatest potential distribution in both periods ( $50 \%$ of the distribution on the data), and the median corresponding to the center of the box, only being observed in a symmetrical distribution in the second period.
A)

ALTITUDINAL DISTRIBUTION CURRENT POTENTIAL DISTRIBUTION

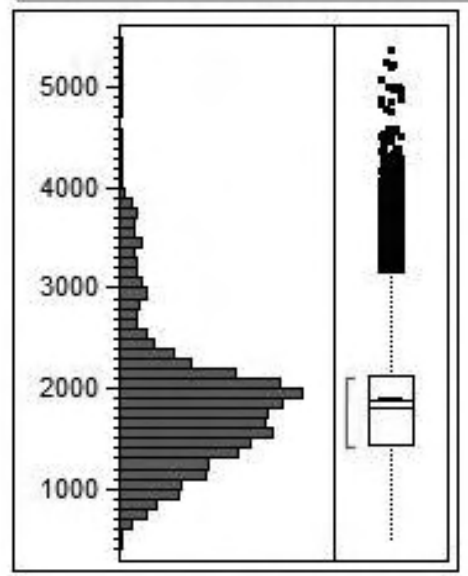

B)

ALTITUDINAL DISTRIBUTION

\section{PERIOD 1}

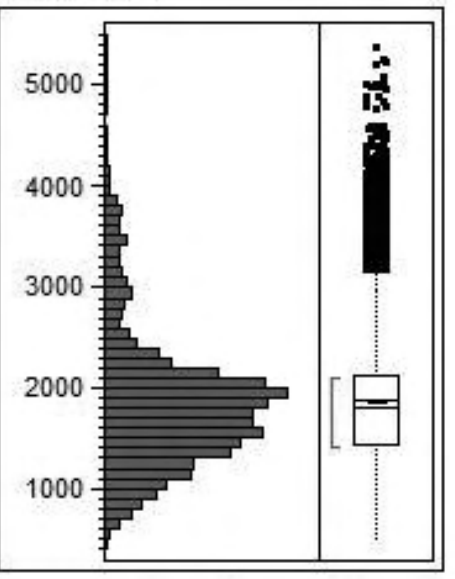

C)

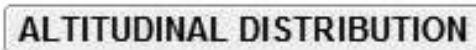

PERIOD 2

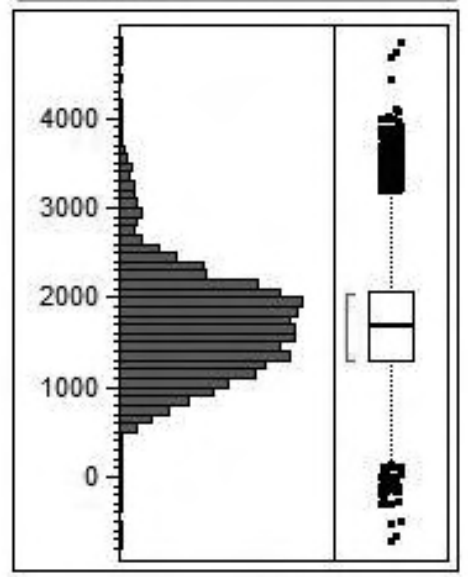

Figure 2. Altitudinal distribution of the current potential distribution models produced under two periods for Magnolia schiedeana. A) Current potential distribution. B) Period 1 (year 2040). C) Period 2 (year 2080). 
Table 2. Potential distribution of Magnolia schiedeana produced under two periods within Protected Natural Areas in Mexico. Area measurements in $\mathrm{km}^{2}$ and percentage of total area (\%).

\begin{tabular}{|c|c|c|c|c|c|c|c|}
\hline \multirow[t]{2}{*}{$\begin{array}{l}\text { Protection } \\
\text { level }\end{array}$} & \multirow[t]{2}{*}{ Protected Natural Area } & \multicolumn{2}{|c|}{$\begin{array}{l}\text { Potential } \\
\text { distribution } \\
\text { current }\end{array}$} & \multicolumn{2}{|c|}{$\begin{array}{c}\text { Distribution } \\
\text { under period } 1 \\
\text { (year 2040) }\end{array}$} & \multicolumn{2}{|c|}{$\begin{array}{l}\text { Distribution } \\
\text { under period } 2 \\
\text { (year 2080) }\end{array}$} \\
\hline & & Area & $(\%)$ & Area & $(\%)$ & Area & $(\%)$ \\
\hline \multirow[t]{42}{*}{ Federal } & Barranca de Metztitlán & 945.23 & 98.41 & 946.48 & 98.54 & 952.17 & 99.13 \\
\hline & Benito Juárez & 11.01 & 40.22 & 11.01 & 40.22 & 2.86 & 10.44 \\
\hline & Bosencheve & 85.46 & 81.92 & 96.43 & 92.43 & 70.78 & 67.84 \\
\hline & Cañón del Río Blanco & 489.65 & 87.92 & 493.17 & 88.55 & 450.42 & 80.87 \\
\hline & Cañón del Sumidero & 34.38 & 15.77 & 26.46 & 12.14 & 8.41 & 3.85 \\
\hline & Cerro de Garnica & 9.36 & 96.69 & 9.96 & 100 & 9.96 & 100 \\
\hline & Ciénegas del Lerma & ------- & ------- & 0.53 & 1.75 & ------- & ------- \\
\hline & Cobio Chichinautzin & 53.56 & 14.35 & 82.99 & 22.24 & 3.61 & 0.96 \\
\hline & Cofre de Perote & 117 & 100 & 117 & 100 & 117 & 100 \\
\hline & Cuenca Hidrográfica del Río Necaxa & 398.49 & 95.72 & 401.13 & 96.35 & 405.88 & 97.49 \\
\hline & Cumbres de Monterrey & 496.63 & 27.99 & 388.83 & 21.91 & 303.47 & 17.10 \\
\hline & Cumbres del Ajusco & 9.2 & 100 & 9.2 & 100 & 9.2 & 100 \\
\hline & Desierto de los leones & 15.29 & 100 & 15.29 & 100 & 15.29 & 100 \\
\hline & El Chico & 27.39 & 100 & 27.39 & 100 & 27.39 & 100 \\
\hline & El Cimatario & 0.89 & 3.63 & 2.8 & 11.43 & 0.95 & 3.88 \\
\hline & El Potosí & 20.45 & 95.87 & 21.33 & 100 & 20.38 & 95.54 \\
\hline & El Tepozteco & 5.26 & 2.26 & 12.11 & 5.20 & ------- & ------ \\
\hline & El Gogorrón & 21.58 & 8.63 & 23.34 & 9.33 & 20.49 & 8.19 \\
\hline & Insur. José María Morelos & ------- & ------- & 1.04 & 2.40 & 0.08 & 0.18 \\
\hline & Insur. Miguel Hidalgo y Costilla & 15.8 & 100 & 15.8 & 100 & 15.8 & 100 \\
\hline & Iztaccíhuatl-Popocatépetl & 269.84 & 67.76 & 269.84 & 67.76 & 8.03 & 2.01 \\
\hline & Lagunas de Monte bello & 41.17 & 68.36 & 22.2 & 36.86 & 17.12 & 28.42 \\
\hline & Lagunas de Zempoala & 38.16 & 79.66 & 47.25 & 98.64 & 11.39 & 23.77 \\
\hline & Los Mármoles & 158.05 & 68.27 & 158.05 & 68.27 & 149.02 & 64.37 \\
\hline & Malinche o Matlalcuéyatl & 126.12 & 27.59 & 125.25 & 27.40 & 54.77 & 11.98 \\
\hline & Mariposa Monarca & 456.73 & 81.18 & 467.97 & 83.18 & 429.97 & 76.42 \\
\hline & Montes Azules & 3.33 & 0.10 & 5.53 & 0.16 & 22.33 & 0.67 \\
\hline & NAHA & 23.22 & 60.35 & 29.93 & 77.80 & 30.32 & 78.81 \\
\hline & Nevado de Colima & 25.72 & 26.79 & 24.07 & 25.07 & 8.03 & 8.36 \\
\hline & Nevado de Toluca & 467.84 & 100 & 467.84 & 100 & 467.84 & 100 \\
\hline & Pico de Orizaba & 197.5 & 100 & 197.5 & 100 & 197.5 & 100 \\
\hline & Pico de Tancítaro & 4.68 & 1.99 & 5.06 & 2.16 & ------- & ------- \\
\hline & Rayón & 0.1 & 40 & 0.1 & 40 & 0.1 & 40 \\
\hline & Selva del Ocote & 65.35 & 6.45 & 67.99 & 6.71 & 61.34 & 6.05 \\
\hline & Sierra de Álvarez & 96.64 & 57.18 & 97.52 & 57.70 & 91.82 & 54.33 \\
\hline & Sierra de Arteaga & $1,208.2$ & 61.28 & $1,128.8$ & 57.25 & 1021.4 & 51.81 \\
\hline & Sierra fría & 181.62 & 16.20 & 190.98 & 17.03 & 4.4 & 0.39 \\
\hline & Sierra Gorda, Querétaro & 755 & 19.69 & 733.47 & 19.12 & 689.77 & 17.98 \\
\hline & Sierra Gorda, Guanajuato & 367.6 & 15.51 & 399.28 & 16.85 & 404.03 & 17.05 \\
\hline & Sierra del Laurel & 1.77 & 0.92 & 2.58 & 1.34 & 0.44 & 0.22 \\
\hline & Tehuacán-Cuicatlán & 357.24 & 7.28 & 362.52 & 7.39 & 170.92 & 3.48 \\
\hline & $\begin{array}{l}\text { Valle de bravo, Malacatepec, } \\
\text { Tilostoc y Temascaltepec }\end{array}$ & 879.17 & 62.85 & 952.34 & 68.08 & 678.71 & 48.52 \\
\hline \multirow[t]{4}{*}{ State } & Volcán de Tequila & 1.13 & 1.32 & 1.13 & 1.32 & 1.13 & 1.32 \\
\hline & Cerro de la Galaxia & 0.32 & 100 & 0.32 & 100 & 0.32 & 100 \\
\hline & Cerro de las Culebras & 0.35 & 100 & 0.35 & 100 & 0.35 & 100 \\
\hline & Cerro de Macuiltépec & 0.28 & 100 & 0.28 & 100 & 0.28 & 100 \\
\hline
\end{tabular}


Table 2. Continuation

\begin{tabular}{|c|c|c|c|c|c|c|c|}
\hline \multirow[t]{2}{*}{$\begin{array}{l}\text { Protection } \\
\text { level }\end{array}$} & \multirow[t]{2}{*}{ Protected Natural Area } & \multicolumn{2}{|c|}{$\begin{array}{l}\text { Potential } \\
\text { distribution } \\
\text { current }\end{array}$} & \multicolumn{2}{|c|}{$\begin{array}{l}\text { Distribution } \\
\text { under period } 1 \\
\text { (year 2040) }\end{array}$} & \multicolumn{2}{|c|}{$\begin{array}{l}\text { Distribution } \\
\text { under period } 2 \\
\text { (year 2080) }\end{array}$} \\
\hline & & Area & $(\%)$ & Area & $(\%)$ & Area & $(\%)$ \\
\hline \multirow[t]{12}{*}{ State } & Ciénega del Fuerte & 42.69 & 100 & 42.69 & 100 & 42.69 & 100 \\
\hline & El Tejar Garnica & 0.92 & 100 & 0.92 & 100 & 0.92 & 100 \\
\hline & Francisco Javier Clavijero & 0.89 & 100 & 0.89 & 100 & 0.89 & 100 \\
\hline & La Martinica & 1.18 & 100 & 1.18 & 100 & 1.18 & 100 \\
\hline & Molino de San Roque & 0.17 & 100 & 0.17 & 100 & 0.17 & 100 \\
\hline & Pacho Nuevo & 0.02 & 100 & 0.02 & 100 & 0.02 & 100 \\
\hline & Pancho Poza & 0.56 & 100 & 0.56 & 100 & 0.56 & 100 \\
\hline & Predio Barragan & 0.01 & 100 & 0.01 & 100 & 0.01 & 100 \\
\hline & Río Filobobos y su Entorno & 93.68 & 88.98 & 105.28 & 100 & 92.32 & 87.68 \\
\hline & San Juan del Monte & 6.09 & 100 & 6.09 & 100 & 6.09 & 100 \\
\hline & San Pedro del Monte & 4.40 & 100 & 4.40 & 100 & 4.40 & 100 \\
\hline & Sierra de Ontontepec & 151.52 & 100 & 151.52 & 100 & 151.52 & 100 \\
\hline
\end{tabular}

Comparison of the current and future distribution with the Protected Natural Areas. Neither the current potential distribution nor that presented under either periods of climate change, coincide with the distribution of federally decreed PNAs in the state of Veracruz. However, they coincide with such PNAs in states that include: Guanajuato, San Luis Potosi, Hidalgo, Tlaxcala, Puebla, Estado de Mexico, among others (Table 2). According to the state Protected Natural Areas in central Veracruz, we can observe a coincidence of $100 \%$ in the area decreed in 14 PNAs (Figure 1B).

\section{Discussion}

Problems of TMCF in Mexico. The future climate scenarios are alarming for $\mathrm{TMCF}$ and are expected to contribute to the decrease in the distribution of many species (Foster, 2001). According to Ponce-Reyes et al. (2012), the TMCF in Mexico has a distribution of $17,320 \mathrm{~km}^{2}$, of which only $11 \%\left(2,045 \mathrm{~km}^{2}\right)$ are protected by ANPs. It is expected that by the year 2080 this protected area of $11 \%$ will be reduced between $68-76 \%$, with a distribution remaining of only between 1,390-1,554 $\mathrm{km}^{2}$ within them. Specifically, for the region of the Sierra Madre Oriental, the TCMF is expected to decrease from the remaining $45 \%$ of its distribution to $0.87 \%$ (decreased from 1,694 to $33 \mathrm{~km}^{2}$ respectively) due to climate change, along with the current rate of land use change (Tejeda, 2009; Ponce-Reyes et al., 2012).

Current condition of Magnolia schiedeana. This species occurs in the later stages of succession, so this requires mature stages of succession for its establishment (Vázquez et al., 1995; Sánchez-Velasquez et al., 2008). Unfortunately, their populations of $M$. schiedeana are small (between 40 and 380 individuals) and distributed in small fragments of TMCF in the center of the Veracruz state (Vásquez-Morales et al., unpubl. data), and have varying degrees of disturbance and edge effects (Williams-Linera et al., 2002).

The Mexican law for the protection of species (NOM059-2010) includes Magnolia schiedeana as a threatened species. Its habitat (TMCF) is also highly threatened due to heavy anthropogenic pressures caused by the changes in land use, to the point of concluding they could well be extinct this century (SEMARNAT, 2010; Ponce-Reyes et al., 2012; Rojas-Soto et al., 2012).

On the other hand, Magnolia schiedeana shows a very specific reproduction system through its relationship with the endemic beetle Cyclocephala jalapensis Casey (Dieringer and Espinosa, 1994). However, according of one ongoing study (for three years) in two small populations of $M$. schiedeana in the center of the state of Veracruz, the growth rates $(\lambda)$ were $>1$, indicating the persistence and growth of both populations and no significant decrease over time (Vasquez-Morales et al., unpubl. data).

Impact of climate change on Magnolia schiedeana. So far, there are few studies about the impact of global climate change on the great biodiversity of Mexico (Trejo et al., 2011). In recent decades, studies have focused on modeling the impact of climate change on ecosystems (Still et al., 1999; Estrada-Contreras, 2010; Rojas-Soto et al., 2012), populations (Téllez-Valdés et al., 2006; McKenney et al., 2007), and species distribution, among others (Téllez et al., 2007; Lira et al., 2009).

Similar studies from other countries (South Africa, India) have made it possible to foresee the expansion of conservation areas and endemic species of commercial interest (Hannah et al., 2005), as well as endangered species (Irfan-Ullah et al., 2007). Some researchers have questioned this type of studies (Pearson and Dawson, 2003; Pearson, 2006); however, the results are considered useful because they allow 
visualizing the potential effect of climate change will have on biodiversity (Levinsky et al., 2007).

The results obtained in this study suggest a decrease in the range of Magnolia schiedeana with respect to both periods $(0.36$ and $1.94 \%)$, well below contractions reported for the distribution of $M$. macrophylla, $M$. virginiana, and $M$. acuminata in a range of $36-93 \%$ with three general circulation models (The Canadian GCM, the UK based Hadley GCM, and the Australian-based Commonwealth Scientific and Industrial Research Organization GCM), in two emission scenarios (A2 and B2; Iverson and Prasad, 1998; McKenney et al., 2007).

Magnolia schiedeana for the periods 2040 and 2080 would suffer a shift to the North and Northeast of Veracruz, Mexico, retaining more than $90 \%$ of its potential distribution. Future environmental conditions favorable for $M$. schiedeana, were in the areas of the Biosphere Reserve Sierra Gorda in Querétaro, Barranca de Metztitlán in Hidalgo, National Park Los Mármoles and El Chico in Hidalgo, and Protected Area Cuenca del río Necaxa in Hidalgo and Puebla. So, these sites should be considered strategic for in situ conservation programs.

Conservation measures. We propose Magnolia schiedea$n a$ reintroduction programs and rehabilitation of the following natural protect areas (PNA) in the central Veracruz State: Cerro de las Culebras, Cerro de la Galaxia, Cerro de Macuiltépetl, El Tejar Garnica, Francisco Javier Clavijero, La Martinica, Molino de San Roque, Pacho Nuevo and Predio Barragan. In the future, PNAs will be refuge and genetic conservation of $M$. schiedeana (Hannah et al., 2007; Newton et al., 2008; CONABIO, 2010; CONANP, 2010). Therefore, it is necessary to create new protected areas in central Veracruz that could be used as biological corridors, taking into account the benefit of the bird dispersion, allowing the movement of M. schiedeana in both periods (Newton et al., 2008).

Limitations of bioclimatic models. Levinsky et al. (2007) recognize the limitations of bioclimatic models, although these are useful tools that provide a means of understanding the geographical distribution of the species in the present and future (Téllez-Valdés et al., 2006; Iverson and McKenzie, 2013). They also represent an option to plan the distribution of geographical areas for the conservation of biodiversity (Irfan-Ullah et al., 2007; Tingley et al., 2010).

\section{Acknowledgements}

To CONACYT for providing the first author with a scholarship for studies leading to a doctoral degree No.229667, and for its support to the CB-2010-01-000000000156053 project. To the program PAPIIT IN216912, for its support in the generation of climatic layers. To Dr. Diana Pérez-Staples,
Dr. Blas M. Benito and the various anonymous reviewers for providing many useful comments and suggestions.

\section{Literature cited}

Aitken S.N., Yeaman S., Holliday J.A., Wang T. and CurtisMcLane S. 2008. Adaptation, migration or extirpation: climatic change outcomes for tree populations. Evolutionary Applications 1:95-111.

Bezaury C.J.E. 2009. El valor de los bienes y servicios que las áreas naturales protegidas proveen a los mexicanos. The Nature Conservancy-Programa México, Comisión Nacional de Áreas Naturales Protegidas, México. D.F.

Bruner A.G., Gullison R.E., Rice R.E. and da Fonseca G.A.B. 2001. Effectiveness of parks in protecting tropical biodiversity. Science 291:125-128.

Bubb P., May I., Miles L. and Sayer J. 2004. Cloud Forest Agenda. UNEP-WCMC, Cambridge.

Cicuzza D., Newton A. and Oldfield S. 2007. The Red List of Magnoliaceae. Fauna and Flora International, Botanic Gardens Conservation International, The Global Trees Campaign, The IUCN/SSC Global Tree Specialist Group, Cambridge.

CONABIO. Comisión Nacional para el Conocimiento y uso de la Biodiversidad. 2010. El Bosque Mesófilo de Montaña en México: Amenazas y Oportunidades para su Conservación y Manejo Sostenible. Comisión Nacional para el Conocimiento y uso de la Biodiversidad, México, D.F.

CONANP. Comisión Nacional de Áreas Naturales Protegidas. 2010. Estrategia de Cambio Climático para Áreas Protegidas. Comisión Nacional de Áreas Naturales Protegidas, Secretaría de Medio Ambiente y Recursos Naturales, México, D.F.

CONANP. Comisión Nacional de Áreas Naturales Protegidas. 2011. Áreas protegidas decretadas. <http://www.conanp.gob. mx/que_hacemos/> (consultado 5 de julio 2011).

Conde C., Estrada F., Martínez B., Sánchez O. and Gay C. 2011. Regional climate change scenarios for México. Atmósfera 24:125-140.

Contreras-Medina R., Luna-Vega I. and Ríos-Muñoz C.A. 2010. Distribución de Taxus globosa (Taxaceae) en México: Modelos ecológicos de nicho, efectos del cambio del uso de suelo y conservación. Revista Chilena de Historia Natural 83:421-433.

Dieringer G. and Espinosa S.J.E. 1994. Reproductive ecology of Magnolia schiedeana (Magnoliaceae), a threatened cloud forest tree species in Veracruz, Mexico. Bulletin of the Torrey Botanical Club 121:154-159.

Dudley N., Stolton S., Belokurov A., Krueger L., Lopoukhine N., MacKinnon K., Sandwith Y. and Sekhran N. 2010. Natural solutions: protected areas helping people cope with climate change. IUCN-WCPA, TNC, UNDP, WCS, The World Bank, WWF, New York.

Elith J., Graham C.H., Anderson R.P., Dudík M., Ferrier S., Guisan A., Hijmans R.J., Huettmann F., Leathwick J.R., Lehmann A., Li J., Lohmann L.G., Loiselle B.A., Manion G., Moritz C., Nakamura M., Nakazawa Y., Overton J.McC.M., Peterson A.T., Phillips S.J., Richardson K., Scachetti-Pereira R., Schapire R.E., Soberón J., Williams S., Wisz M.S. and Zimmermann N. E. 2006. Novel methods improve prediction of species' distributions from occurrence data. Ecography 29:129-151. 
ESRI. Environmental Systems Research Institute. 1999. ArcView 3.2. ESRI Inc., Redlands.

Estrada-Contreras I. 2010. Modelación de los cambios en la distribución de las comunidades vegetales terrestres del estado de Veracruz por efecto del cambio climático global. Tesis maestría, Instituto de Ecología, A.C. Xalapa, Veracruz. 144 pp.

Foster P. 2001. The potential negative impacts of global climate change on tropical montane cloud forests. Earth-Science Reviews 55:73-106.

González-Espinosa M., Meave J.A., Lorea-Hernández F.G., IbarraManríquez G. and Newton A.C. 2011. The Red List of Mexican Cloud Forest Trees. Fauna y Flora International, Botanic Gardens Conservation International, The Global Trees Campaign, The IUCN/SSC Global Tree Specialist Group, Cambridge.

Halpin P.N. 1997. Global climate change and natural-area protection: management responses and research directions. Ecological Applications 7:828-843.

Hannah L., Midgley G., Hughes G. and Bomhard B. 2005. The view from the cape: extinction risk, protected areas, and climate change. Bioscience 55:231-242.

Hannah L., Midgley G., Andelman S., Araújo M., Hughes G., Martinez-Meyer E., Pearson R. and Williams P. 2007. Protected areas needs in a changing climate. Frontiers in Ecology and the Environment 5:131-138.

Hardy J.T. 2003. Climate Change. Causes, Effects, and Solutions. John Wiley \& Sons Ltd, Oxford.

Hilbert D.W., Bradford M., Parker T. and Westcott D.A. 2004. Golden bowerbird (Prionodura newtonia) habitat in past, present and future climates: predicted extinction of vertebrate in tropical highlands due to global warming. Biological Conservation 116:367-377.

Holt R.D. 1990. The microevolutionary consequences of climate change. Trends and Ecology Evolution 5:311-315.

Houlder D.J., Hutchinson M.F., Nix H.A. and McMahon J.P. 2000. ANUCLIM 5.1 User Guide. Centre for Resource and Environmental Studies, Australian National University, Australian Capital Territory, Canberra.

Hutchinson M.F. 1991. The application of thin plate smoothing splines to continent-wide data assimilation. In: Jasper J.D. Ed. BMRC Research Report No. 27. Data Assimilation Systems, pp. 104-113, Bureau of Meteorology, Melbourne.

Hutchinson M.F. 1995a. Interpolating mean rainfall using thin plate smoothing splines. International Journal of Geographical Information Systems 9:385-403.

Hutchinson M.F. 1995b. Stochastic space-time weather models from ground-based data. Agricultural and Forest Meteorology 73:237-264.

Hutchinson M.F. 1997. ANUSPLIN. Version 4.1. User guide. Centre for Resource and Enviromental Studies, The Autralian National University, Australian Capital Territory, Canberra.

Hutchinson M.F. and Glessler P.E. 1994. Splines- more than just a smooth interpolator. Geoderma 62:45-67.

IPCC. Intergovernmental Panel on Climate Change. 2001. Cambio Climático 2001: Informe de Síntesis. Intergovernmental Panel on Climate Change, Geneva.

IPCC. Intergovernmental Panel on Climate Change. 2007. Change Climatic 2007: Impacts, Adaptation and Vulnerability. Cambridge University Press, Cambridge.

Irfan-Ullah M., Amarnath G., Murthy M.S.R. and Peterson A.T. 2007. Mapping the geographic distribution of Aglaia bourdillo- nii (Meliaceae), an endemic and threatened plant, using ecological niche modelling. Biodiversity and Conservation 16:19171925.

Iverson R.L. and McKenzie D. 2013. Tree-species range shifts in a changing climate: detecting, modeling, assisting. Landscape Ecology 28:879-889.

Iverson R.L. and Prasad A.M. 1998. Predicting abundance of 80 tree species following climate change in the Eastern United States. Ecological Monographs 68:465-485.

Jiménez-Ramírez J., Vega-Flores K., Cruz-Duran R., VázquezGarcía J.A. 2007. Magnolia guerrerensis (Magnoliaceae), una especie nueva del bosque mesófilo de montaña del Estado de Guerrero, México. Boletín de la Sociedad Botánica de México 80:73-76.

Jungclaus J.H., Haak H., Latif M. and Mikolajewicz U. 2005. Arctic-North Atlantic interactions and multidecadal variability of the meridional overturning circulation. Journal of Climate 18:4013-4031.

Lawler J.J. 2009. Climate change adaptation strategies for resource management and conservation planning. Annals of the New York Academy of Science 1162:79-98.

Levinsky I., Flemming S., Svenning J.C. and Rahbek C. 2007. Potential impacts of climate change on the distributions and diversity patterns of European Mammals. Biodiversity and Conservation 16:3803-3816.

Li J. and Hilbert D.W. 2008. LIVES: a new habitat modelling technique for predicting the distribution of species' occurrences using presence-only data based on limiting factor theory. Biodiversity and Conservation 17:3079-3095.

Lindenmayer D.B., Nix H.A., McMahon J.P., Hutchinson M.F. and Tanton M.T. 1991. The conservation of Leadbeater's possum, Gymnobelideus leadbeateri (McCoy): a case study of the use of bioclimatic modelling. Journal of Biogeography 18:371-383.

Lindenmayer D.B., Mackey B.G. and Nix H.A. 1996. The bioclimatic domains of four species of commercially important eucalypts from south-eastern Australia. Australian Forestry 59:74-89.

Lira R., Téllez O. and Dávila P. 2009. The effects of climate change on the geographic distribution of Mexican wild relatives of domesticated Cucurbitaceae. Genetic Resources and Crop Evolution 56:691-703.

Magaña R.V.O. 2004. El cambio climático global: comprender el problema. In: Martínez J. and Fernández B.A. Comp. Cambio Climático: Una Visión desde México, pp. 17-27, Secretaria de Medio Ambiente y Recursos Naturales, Instituto Nacional de Ecología, México, D.F.

Magaña V., Méndez J.M., Morales R. and Millán C. 2004. Consecuencias presentes y futuras de la variabilidad y el cambio climático en México. In: Martínez J. and Fernández B.A. Comp. Cambio Climático: Una Visión desde México, pp. 203-213, Secretaria de Medio Ambiente y Recursos Naturales, Instituto Nacional de Ecología, México, D.F.

Malcolm J.R., Liu C., Neilson R.P., Hansen L. and Hannah L. 2006. Global warming and extinctions of endemic species from biodiversity hotspots. Conservation Biology 20:538-548.

Mansourian S., Belokurov A. and Stephenson P.J. 2009. The role of forest protected areas in adaptation to climate change. Unasylva 231/232:63-69.

Markham A. 1998. Potential impacts of climate change on tropical forest ecosystems. Climatic Change 39:141-143. 
McKenney D.W., Pedlar J.H., Lawrence K., Campbell K. and Hutchinson M.F. 2007. Potential impacts of climate change on the distribution of the North American Trees. BioScience 57:939-948.

Midgley G.F., Hannah L., Millar D., Rutherford M.C. and Powrie L.W. 2002. Assessing the vulnerability of species richness to anthropogenic climate change in a biodiversity hotspot. Global Ecology and Biogeography 11:445-451.

Newton A.C., Gow J., Robertson A., Williams-Linera G., Ramírez-Marcial N., González-Espinosa M., Allnutt T.R. and Ennos R.A. 2008. Genetic variation in two rare endemic Mexican trees, Magnolia sharpii and Magnolia schiedeana. Silvae Genetica 57:348-356.

Pearson R.G. 2006. Climate change and the migration capacity of species. Trends in Ecology and Evolution 21:111-113.

Pearson R.G. and Dawson T.P. 2003. Predicting the impacts of climate change on the distribution of species: are bioclimate envelope models useful? Global Ecology and Biogeography 12:361-371.

Peterson A.T. 2009. Phylogeography is not enough: The need for multiple lines of evidence. Frontiers of Biogeography 1:19-25.

Phillips S.J., Anderson R.P. and Schapire R.E. 2006. Maximum entropy modeling of species geographic distributions. Ecological Modelling 190:231-259.

Ponce-Reyes R., Reynoso-Rosales V.H., Watson J.E.M., VanDerWal J., Fuller R.A., Pressey R.L. and Possingham H.P. 2012. Vulnerability of cloud forest reserves in Mexico to climate change. Nature Climate Change 2:448-452.

Pounds J.A., Fogden M.L.P. and Campbell J.H. 1999. Biological response to climate change on a tropical mountain. Nature 398:611-615.

Rojas-Soto O.R., Sosa V. and Ornelas J.F. 2012. Forecasting cloud forest in eastern and southern Mexico: conservation insights under future climate change scenarios. Biodiversity and Conservation 21:2671-2690.

Rzedowski J. 1978. Vegetación de México. Limusa, México, D.F.

Rzedowski J. 1996. Análisis preliminar de la flora vascular de los bosques mesófilos de montaña de México. Acta Botanica de México 35:25-44.

Sáenz-Romero C., Rehfeldt G.E., Crookston N.L., Duval P., StAmant R., Beaulieu J. and Richardson B.A. 2010. Splines models of contemporary, 2030, 2060 and 2090, climates for Mexico and their use in understanding climate-change impacts on the vegetation. Climatic Change 102:595-623.

Sánchez-Velásquez L.R., Ramírez-Bamonde E.S., Andrade-Torres A. and Rodriguez T.P. 2008. Ecología, florística y restauración del bosque mesófilo de montaña. In: Sánchez-Velásquez L.R., Galindo G.J. and Díaz-Fleischer F. Eds. Ecología, Manejo y Conservación de los Ecosistemas de Montaña en México, pp. 9-49, Comisión Nacional para el Uso y Conocimiento de la Biodiversidad, Universidad Veracruzana, Mundi Prensa, México, D.F.

SAS Institute Inc. 2007. SAS/STAT user's guide for personal computers, version 6.08. SAS Institute Inc., Cary.

SEDEMA. Secretaria de Medio Ambiente del Estado de Veracruz. 2012a. Espacios Naturales Protegidos. <http://portal.veracruz. gob.mx/portal/page?_pageid=53,3840525\&_dad=portal\&_ schema=PORTAL> (consultado 23 de enero 2012).

SEDEMA. Secretaria de Medio Ambiente del Estado de Veracruz. 2012b. Áreas Naturales Protegidas. <http://portal.veracruz. gob.mx/portal/page?_pageid=53,3840534\&_dad=portal\&_ schema=PORTAL $>$ (consultado 23 de enero 2012).

SEMARNAT. Secretaria de Medio Ambiente y Recursos Naturales. 2010. NOM-059-SEMARNAT-2010, Protección ambiental-Especies nativas de México de flora y fauna silvestres-Categorías de riesgo, especificaciones para su inclusión, exclusión o cambio-Lista de especies en riesgo.

Soberón J. and Peterson A.T. 2005. Interpretation of models of fundamental ecological niches and species' distributional areas. Biodiversity Informatics 2:1-10.

Still C.J., Foster P.N. and Schneider S.H. 1999. Simulating the effects of climate change on tropical montane cloud forests. Nature 398:608-610.

Tejeda M.A. Comp. 2009. Programa veracruzano ante el cambio climático. Universidad Veracruzana, Instituto Nacional de Ecología, Embajada Británica México, Xalapa.

Téllez O., Hutchinson M.A., Nix H.A. and Jones P. 2011. Desarrollo de coberturas digitales climáticas para México. In: Sánchez R.G., Ballesteros B.C. and Pavón N.P. Eds. Cambio Climático. Aproximaciones para el Estudio de su Efecto sobre la Biodiversidad, pp. 15-23, Universidad Autónoma del Estado de Hidalgo, Pachuca.

Téllez V.O., Dávila P., Ayala M., Gutiérrez K. and Melchor I. 2007. Case studies of the effect of climate change on the flora of Mexico. Journal of Botanic Gardens Conservation International 4:17-21.

Téllez-Valdés O. and Dávila-Aranda P. 2003. Protected areas and climate change: a case study of the cacti of the Tehuacán-Cuicatlán Biosphere Reserve, México. Conservation Biology 17:846853.

Téllez-Valdés O., Chávez H.Y.M., Gómez-Tagle C.H.A. and Gutiérrez G.M.V. 2004. Modelaje bioclimático, una herramienta para desarrollar estrategias de manejo forestal: estudio de caso en cuatro especies mexicanas de Pinus (Pinaceae). Ciencia Forestal 29:61-82.

Téllez-Valdés O., Dávila-Aranda P. and Lira-Saade R. 2006. The effects of climate change on the long-term conservation of Fagus grandiflora var. mexicana, an important species of the Cloud Forest in Eastern México. Biodiversity and Conservation 15:1095-1107.

Tews J. 2007. Biodiversity and climate change: A modeling perspective. In: Schwartz J. Ed. Focus on Biodiversity Research, pp. 27-41, Nova Science Publisher Inc, New York.

Tingley R., Herman T.B., Pulsifer M.D., McCurdy D.G. and Stephens J.P. 2010. Intra-specific niche partitioning obscures the importance of fine-scale habitat data in species distribution models. Biodiversity and Conservation 19:2455-2467.

Torres R.J.M. and Guevara S.A. 2002. El potencial de México para la producción de servicios ambientales: captura de carbono y desempeño hidráulico. Gaceta Ecológica 63:40-59.

Trejo I., Martínez-Meyer E., Calixto-Pérez E., Sánchez-Colón S., Vázquez-de la Torre R. and Villers-Ruiz L. 2011. Analysis of the effects of climate changes on plants communities and mammals in México. Atmósfera 24:1-14.

Vázquez G.J.A., Cuevas G.R., Cochrane T.S., Iltis H.H., Santana M.F.J. and Guzmán H.L. 1995. Flora de Manantlán. Plantas Vasculares de la Reserva de la Biosfera Sierra de Manantlán Jalisco-Colima, México. Comisión Nacional para el Conocimiento y Uso de la Biodiversidad, Universidad de Guadalajara, Guadalajara. 
Vázquez-García J.A., Muñiz-Castro M.A., de Castro-Arce E., Murguía A.R., NuñoR.A.T., and Cházaro-B. M.J. 2012. Twenty new neotropical tree species of Magnolia (Magniliaceae). In: Salcedo P.E., Hernández A.E., Vázquez G.J.A., Escoto G.T. and Díaz E.N. Eds. Recursos Forestales del Occidente de México: Diversidad, Producción, Manejo, Aprovechamiento y Conservación, pp. 91-130, Centro Universitario de Ciencias Exactas e Ingenierías, Centro Universitario de Ciencias Biológicas y Agropecuarias, Universidad de Guadalajara, México, D.F.

Villaseñor J.L. 2010. El Bosque Húmedo de Montaña en México y sus Plantas Vasculares: Catálogo Florístico-Taxonómico.
Comisión Nacional para el Conocimiento y Uso de la Biodiversidad, Universidad Nacional Autónoma de México, México, D.F.

Villaseñor J.L. and Téllez-Valdés O. 2004. Distribución geográfica potencial de las especies del género Jefea (Asteraceae) en México. Anales del Instituto de Biología, Universidad Nacional Autónoma de México, Serie Botánica 75:205-220.

Williams-Linera G., Manson R.H. and Isunza V.E. 2002. La fragmentación del bosque mesófilo de montaña y patrones de uso del suelo en la región oeste de Xalapa, Veracruz, México. Madera y Bosques 8:73-89.

Received: August 10th, 2013

Accepted: January 15th, 2014 